\title{
LIMESTONES OF WESTERN NEWFOUNDLAND THAT MAGNETIZED BEFORE DEVONIAN FOLDING BUT AFTER MIDDLE ORDOVICIAN LITHIFICATION
}

$$
\text { J.P. Hodych }
$$

Department of Earth Sclences, Memorial University of Newfoundland

Abstract. A positive fold test and a negative conglomerate test help determine when and how stable remanence was acquired in the Middle Ordovician Table Head Group limestones of the Port au Port Peninsula of Newfoundland. The limestones magnetized after lithification and incorporation as clasts into a Middle Ordovician breccia. Hence, the limestones do not carry a detrital or other primary remanence despite their very low conodont colour alteration index of 1 . The remanence may be thermoviscous or diagenetic and was acquired before Devonian folding. This suggests the need for caution in interpreting paleomagnetic results from other early Paleozoic limestones whose remanence resides in magnetite of blocking temperature lower than $400^{\circ} \mathrm{C}$.

\section{Introduction}

The Middle Ordovician Table Head Group carbonates (mostly limestones) of the Port au Port Peninsula of western Newfoundland have been shown by Deutsch and Prasad (1987) to typically carry a remanence stable to about $450^{\circ} \mathrm{C}$ and directed southeasterly at about $41^{\circ}$ below horizontal. Deutsch and Prasad (1987) interpreted this as an original Middle Ordovician remanence but pointed out that a proper fold test had not been carried out. Both a fold test and a conglomerate test of when the remanence was acquired will be described in the present paper. These tests also shed light upon the mechanism of remanence acquisition and upon the likelihood of obtaining a reliable magnetostratigraphy for carbonates near the Cambro-Ordovician boundary at the proposed world stratotype section at Green Point. (Figure 1).

\section{Sampling and Measurement}

Deutsch and Prasad (1987) collected their Table Head Group carbonates from the Port au Port Peninsula at the West Bay and Aguathuna quarries where the gentle dip of bedding did not allow a meaningful fold test. Prasad (1986) had also collected from sites at Cape Cormorant where bedding dipped steeply, but large dispersion in stable remanence directions led Deutsch and Prasad (1987) to exclude these sites from discussion. My fold test is based on block sampling at sites numbered 1 to 6 in Figure 1.

I also attempt the first conglomerate test for the Port au Port Peninsula at site 1 (Black Cove) where Table Head Group 1imestones occur as clasts in a limestone conglomerate-breccia at the top of the Table Head Group (Klappa et al 1980). Those

Copyright 1989 by the American Geophysical Union.

Paper number 88GL04097.

0094-8276/89/88GL-04097\$03.00

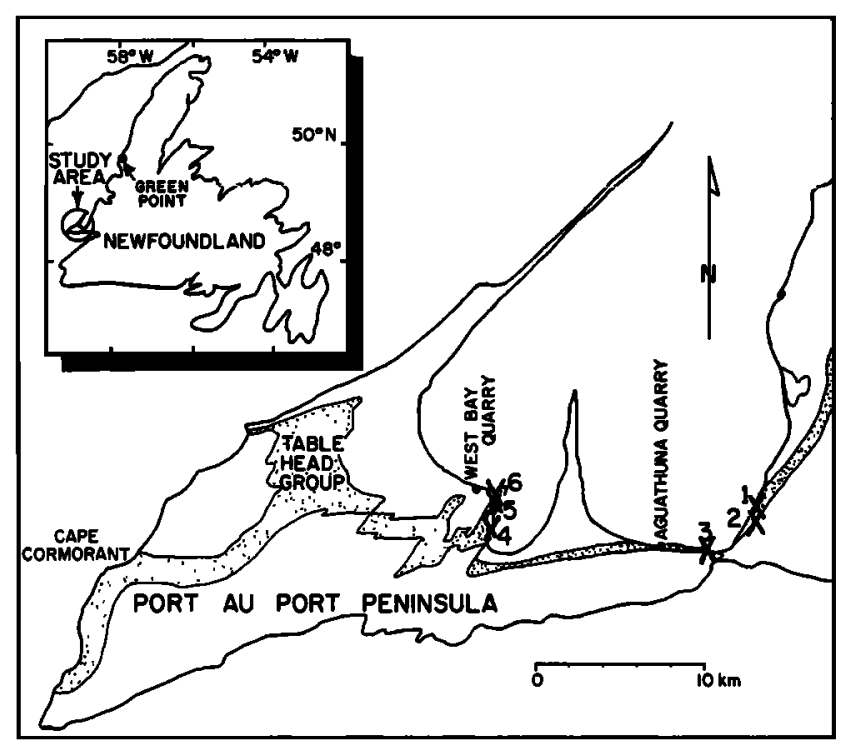

Fig. 1. Paleomagnetic sampling sites 1 to 6 in the Middle Ordovician Table Head Group carbonates (shown stippled) on the Port au Port Peninsula of western Newfoundland. Geology after Williams (1985).

clasts that were large, flat and bedded were selected for sampling. The bedding plane attitude of each clast was measured in the field but original tops of beds could not be determined. The clasts were later reoriented and drilled in the laboratory.

Cylindrical specimens of about $2.1 \mathrm{~cm}$ length and $2.3 \mathrm{~cm}$ diameter were cut from each of the oriented block samples. Guided by the experience of Deutsch and Prasad (1987) who found thermal demagnetization more effective than alternating field (AF) demagnetization, one specimen from each block sample was first AF demagnetized using 5 and then $10 \mathrm{mT}$; then it was thermally demagnetized by heating successively to $200,300,330,360,390$, 420 and $450^{\circ} \mathrm{C}$ in fleld - free space. Remanent magnetization was measured initialiy (NRM) and after each step in demagnetization. Schonstedt GSD-1 and TSD-2 demagnetizers and a CTF cryogenic magnetometer were used.

\section{Results of the Conglomerate Test}

On demagnetizing, the remanence of clasts of Table Head Group limestone in the breccia at site 1 behaves in a similar manner to that described for the Table Head Group by Deutsch and Prasad (1987). Figure 2 shows the change in remanence on demagnetization for two limestone breccia clasts with very different attitude of clast bedding. AF demagnetization to $10 \mathrm{mI}$ typically reduces the 

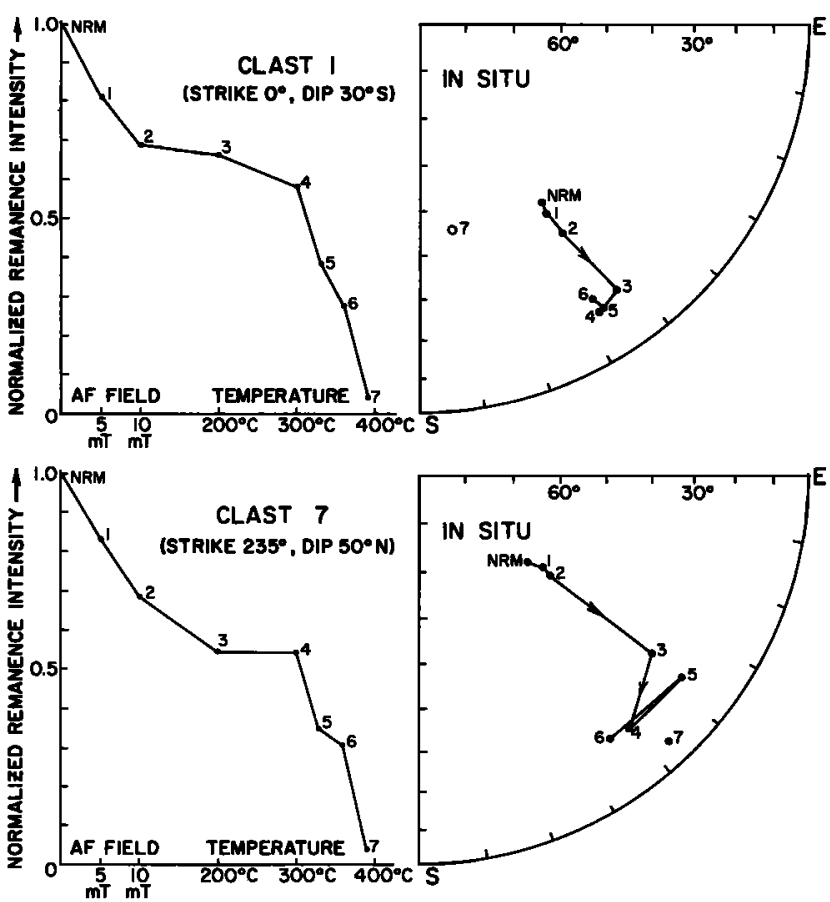

Fig. 2. Remanent magnetization change on demagnetization shown for two clasts of Table Head Group limestone with very different bedding orientation in the breccla at site 1 . Remanence directions are shown in equal-area stereographic projection by solid circles for downward and open circles for upward directions with NRM indicating the in situ natural remanence direction and numbers 1 to 7 indicating directions upon successive demagnetization to $5 \mathrm{mT}, 10 \mathrm{mT}, 200^{\circ}$, $300^{\circ}, 330^{\circ}, 360^{\circ}$, and $390^{\circ} \mathrm{C}$. The corresponding remanence intensity changes are also shown.

remanence intensity by about a quarter and moves the in situ remanence towards a less steep southeasterly direction. The subsequent thermal demagnetization reduces intensity to about 258 of NRM by $360^{\circ} \mathrm{C}$ and generally leads to a stable endpoint before the sample becomes unstable between 390 to $420^{\circ} \mathrm{C}$. The intensity and direction changes on demagnetization are generally less smooth than reported by Deutsch and Prasad (1987) probably because my use of a laboratory with much higher magnetic field gradients and fluctuations led to larger spurious remanences acquired on thermal demagnetization.

of the 16 clasts measured, 11 reach stable endpoints on demagnetization. The stable directions obtained by averaging the directions after demagnetization to $300^{\circ} \mathrm{C}, 330^{\circ}$ and $360^{\circ}$ and sometimes $390^{\circ}$ from each of these 11 clasts have been plotted in Figure 3 both before and after correction for tilt of the bedding of the individual clasts. The scatter of remanence directions is much greater after this tilt correction ( $\alpha_{95}$ increasing from $10^{\circ}$ to $23^{\circ}$ ) and would likely be further increased if we could identify and correct for those clasts that are overturned. Certainly remanence is not at a constant angle to clast bedding as expected of primary remanence. This negative conglomerate test shows that the clasts were magnetized after incorporation into the breccia bed.
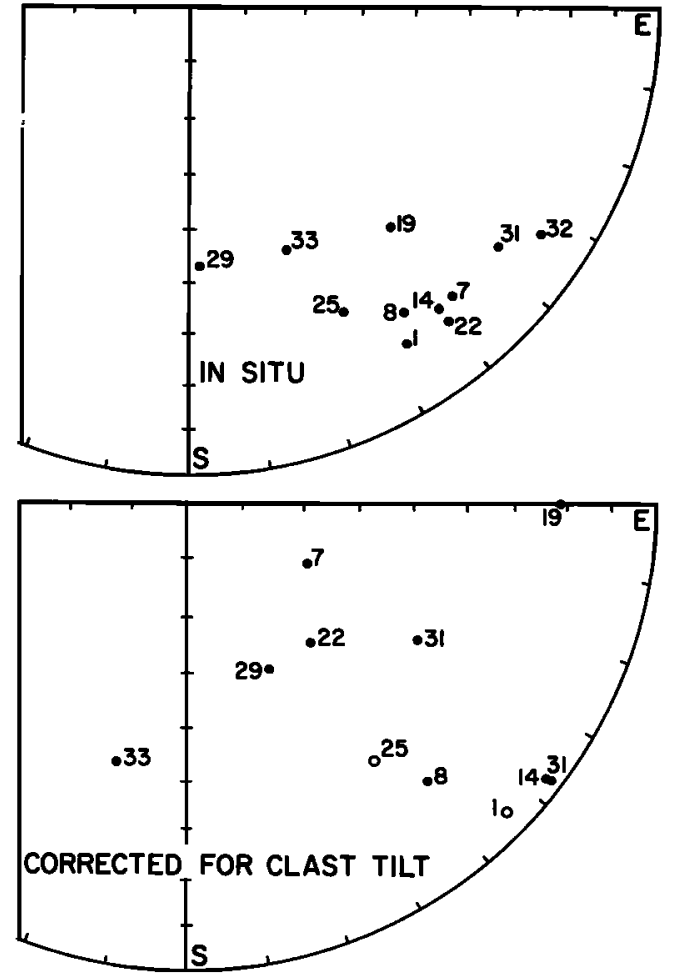

Fig. 3. Characteristic remanence directions of stable clasts of Table Head Group limestone in the Middle Ordovician conglomerate-breccia at site 1 before and after correcting for tilt of the bedding of each clast (assuming none are overturned).

\section{Results of the Fold Test}

Sites 2 to 6 were in limestones of the Table Head Group. On demagnetization, these behave much like the limestone clasts in the breccia at site 1. That is, most samples attain a stable endpoint before becoming unstable between $390^{\circ}$ to $420^{\circ} \mathrm{C}$. However, all four samples at site 6 and two of the four samples at site 3 are unstable; hence, these two sites are not further used (even though the two stable samples at site 3 support the positive fold test).

The average stable remanence direction for each stable site is listed in Table 1 along with the usual range of blocking temperatures over which each stable sample's directions were averaged to obtain its characteristic direction. As seen in Figure 4 , the site mean remanences are much more closely clustered after tilt correction. This is a positive fold test at 998 confidence using the test of McElhinny (1964). This shows that remanence was acquired before folding which is thought to be of Devonian age (Williams 1985). Averaging the site means of Table 1 gives a mean tilt-corrected direction ( $\left.\mathrm{D}-157^{\circ}, \mathrm{I}=47^{\circ}, \alpha_{95}=11^{\circ}\right)$ not significantly different from that reported by Deutsch and Prasad (1987) and yields a virtual paleopole at $11^{\circ} \mathrm{N}, 142^{\circ} \mathrm{E}\left(\mathrm{dm}=9^{\circ}, \mathrm{dp}-11^{\circ}\right)$.

\section{Discussion}

The remanence of the Table Head Group carbonates likely resides in magnetite (Deutsch 
TABLE 1. Mean Characteristic Remanence Direction For Each Stable Site

\begin{tabular}{|c|c|c|c|c|c|c|c|c|}
\hline \multirow[t]{2}{*}{$\overline{\text { Site }}$} & \multicolumn{3}{|c|}{ Attitude of Bedding } & \multicolumn{4}{|c|}{ Characteristic Remanence } & \multirow{2}{*}{$\begin{array}{l}\text { Blocking } \\
\text { Temperatures } \\
\text { Used }\end{array}$} \\
\hline & strike & Dip & N/No & D & $\mathbf{I}$ & $\mathbf{k}$ & $\alpha_{95}$ & \\
\hline $\begin{array}{l}1 \\
2 \\
4 \\
5\end{array}$ & $\begin{array}{r}208^{\circ} \\
200^{\circ} \\
245^{\circ} \\
24^{\circ}\end{array}$ & $\begin{array}{l}23^{\circ} \mathrm{W} \\
14^{\circ} \mathrm{W} \\
52^{\circ} \mathrm{N} \\
48^{\circ} \mathrm{S}\end{array}$ & $\begin{array}{l}11 / 16 \\
3 / 4 \\
5 / 5 \\
3 / 4\end{array}$ & $\begin{array}{l}151.3^{\circ} \\
154.4^{\circ} \\
153.5^{\circ} \\
168.3^{\circ}\end{array}$ & $\begin{array}{l}44.2^{\circ} \\
36.6^{\circ} \\
55.4^{\circ} \\
49.9^{\circ}\end{array}$ & $\begin{array}{l}23.7 \\
70.7 \\
30.2 \\
71.1\end{array}$ & $\begin{array}{r}9.6^{\circ} \\
14.8^{\circ} \\
14.2^{\circ} \\
14.7^{\circ}\end{array}$ & $\begin{array}{l}300 \text { to } 390^{\circ} \mathrm{C} \\
300 \text { to } 420^{\circ} \mathrm{C} \\
300 \text { to } 420^{\circ} \mathrm{C} \\
300 \text { to } 390^{\circ} \mathrm{C}\end{array}$ \\
\hline
\end{tabular}

Sites are as shown in Fig. 1; N/No, number of sample characteristic directions used in computing site mean/number of samples measured (each from an independently oriented block); $D$, declination; I inclination; k Fisher's precision parameter; $\alpha_{95}$, radius of the circle of 958 confidence; beds restored to horizontal by tilting about the strike; samples demagnetized as explained in text.

and Prasad 1987) which one might have expected to carry a Middle Ordovician detrital remanence (Prasad 1986, p. 162). Retention of detrital remanence should have been aided by lithification having occurred soon after deposition; rapid lithification is shown by the clasts collected from the Middle Ordovician breccla at site 1 being undeformed despite being large and thin (of average dimensions $25 \times 18 \times 4 \mathrm{~cm}$ ) proving that the limestone in the clasts had been both deposited and lithifled in the Middle Ordovician before incorporation into the breccia. Nevertheless, the negative conglomerate test proves that the Table Head Group clasts magnetized after incorporation
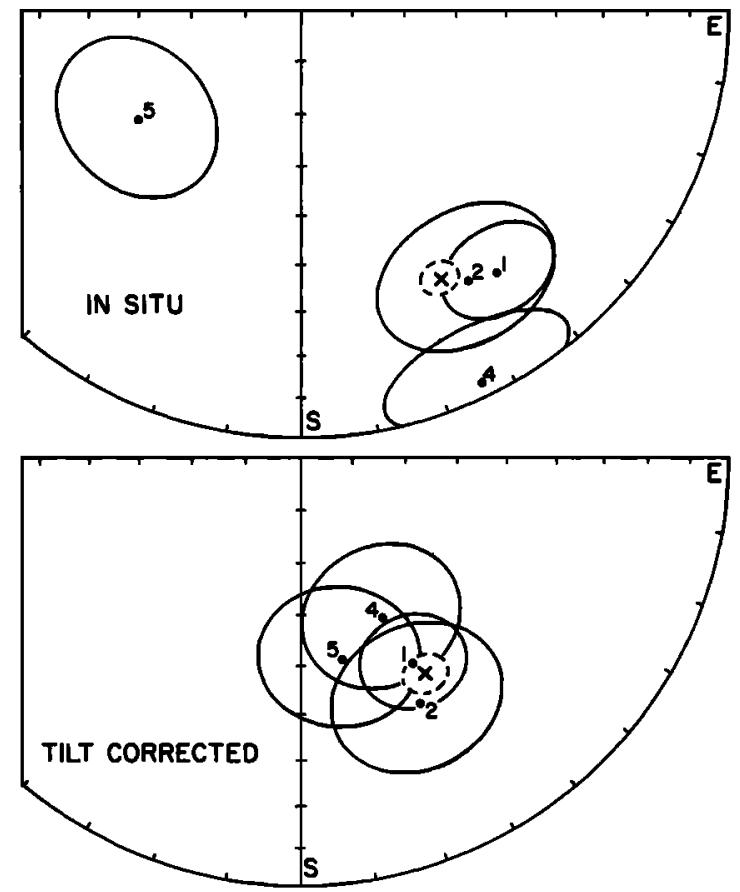

Fig. 4. Mean characteristic remanence directions for the stable sites $1,2,4$ and 5 with their circles of 958 confidence shown in situ and after correcting for tilt of bedding (that of the conglomerate bed rather than the Individual clasts in the case of site 1 ). The cross shows the mean characteristic remanence direction obtained by Deutsch and Prasad (1987) for the Table Head Group with its circle of 958 confidence shown dashed.
Into the breccia and hence after lithification of the limestone in the clasts, ruling out a detrital remanence.

Could the Table Head Group have remagnetized during post-lithification heating? The conodont colour alteration index is only 1 for these carbonates (Nowlan and Barnes 1987) suggesting a maximum temperature of about $65^{\circ} \mathrm{C}$ if applied for a million years according to the dry air Arrhenius plots of Epstein et al (1977). This would only be enough to remagnetize magnetite with blocking temperatures below $200^{\circ} \mathrm{C}$ according to the theory of Pullaiah et al (1975). However, this theory may greatly underestimate the maximum blocking temperature that will be remagnetized as suggested by the fleld examples of Kent (1985) and Jackson and Van der Voo (1986). As shown by Enkin and Dunlop (1988), this underestimation is probably due to the magnetite being in larger than singledomain grains. Hence because the magnetite in the Table Head Group limestone could be multidomain and because the dry air Arrhenius plots of Epstein et al (1977) may underestimate paleotemperature (Hodych et al 1985), it is possible that the stable remanence in the Table Head Group is thermoviscous. If so, the heating cycle responsible was not likely due to the Acadian orogeny since the remanence predates Devonian folding but it may have been associated with burial under the Humber Arm Allochthon in the Middle Ordovician.

It is also possible that the magnetization was acquired during diagenetic growth of magnetite. For example, Jackson et al (1988) argue that Devonian carbonates of New York State carry a stable chemical remanence due to growth of authigenic magnetite caused by temperaturedependent diagenesis triggered by orogenic fluids. Such a mechanism of remanence acquisition in the Table Head Group might be associated with the Taconic Orogeny in the Ordovician. It could even be associated with the Acadian Orogeny in the Devonian provided the orogenic fluids triggered magnetite production before folding which seems possible according to the model of oliver (1986). However, Devonian acquisition of magnetization is not favoured by the paleopole position yielded by the Table Head Group.

The negative conglomerate test for the Table Head Group of the Port au Port Peninsula bars using its remanence to help define a midOrdovician paleopole for North America (as 
attempted by Deutsch and Prasad, 1987). Indeed, the present study auggests that caution is needed in defining polar wander paths using any early Paleozoic limestones whose remanence resides in magnetite of blocking temperature lower than $400^{\circ} \mathrm{C}$. Caution will also be needed in using such rocks for magnetostratigraphy. For example, Ripperdan and Kirschvink (1988), mostly using carbonates, find evidence of a normal polarity interval near the Cambro-Ordovician boundary at some proposed world stratotype sections, but not at others including that at Green Point, western Newfoundland. The negative conglomerate test for the Port au Port Peninsula suggests that the carbonates at Green Point may also have magnetized after lithification since the remanence at Green Point is likely carried by magnetite of similar blocking temperatures (judging from carbonates at Cow Head near Green Point studied by Prasad, 1986) and was heated to slightly higher temperatures (a conodont colour alteration index of 1.5 being reported by Nowlan and Barnes, 1987). Postlithification magnetization at Green Point is also suggested by Prasad's (1986, p. 188) observation that many of the carbonate clasts in a Middle Ordovician breccia at Cow Head magnetized after incorporation into the breccia.

Acknowledgements. I thank E.R. Deutsch, J.N. Prasad and C.R. Barnes for discussion and encouragement. I am indebted to $S$. Stenzel for providing conglomerate locations. M. Tubrett did most of the paleomagnetic measurements. The research was supported by the Natural Sclences and Engineering Research Council of Canada.

\section{References}

Deutsch, E.R. and Prasad, J.N. Ordovician paleomagnetic results from the $S t$. George and Table Head carbonates of western Newfoundland, Càn. J. Earth Sc1., 24, 1785-1796, 1987.

Enkin, R.J. and Dunlop, D.J. The demagnetization temperature necessary to remove viscous remanent magnetization. Geophys. Res. Lett. , 15, 514-517, 1988 .

Epstein, A.G., Epstein, J.B. and Harris, L.D., Conodont colour alteration-an Index to organic metamorphism. U.S. Geol, Surv. Prof. Paper 995, 27 p., 1977.

Hodych, J.P., Patzold, R.R. and Buchan, K.L., Chemical remanent magnetization due to deep burial diagenesis in oolitic hematite-bearing ironstones of Alabama, Phys. Barth Planet. Inter., 37, 261-284,1985.
Jackson, M., McCabe, C., Ballard, M.M. and Van der Voo, R., Magnetite authigenesis and diagenetic paleotemperatures across the northern Appalachian basin, Geology, 16, 592595,1988

Jackson, M. and Van der Voo, R., Thermally activated viscous remanence in some magnetite and hematite-bearing dolomites, Geophys. Res. Lett., 13, 1434-1437, 1986.

Kent, D.V., Thermoviscous remagnetization in some Appalachian IImestones, Geophys. Res. Lett, 12, 805-808, 1985.

Klappa, C.F., Opalinski, P.R. and James N.P., Middle Ordovician Table Head Group of western Newfoundland: a revised stratigraphy, Gan. J. Earth Sc1, 17, 1007-1019, 1980.

McElhinny, M.W., statistical significance of the fold test in paleomagnetism, Geophys. $J$. $R$. Astr. Soc., $8,338-340,1964$.

Nowlan, G.S. and Barnes, C.R., Thermal maturation of Paleozoic strata in eastern Canada from conodont colour alteration index (CAI) data with implications for burial history, tectonic evolution, hotspot tracks and mineral and hydrocarbon exploration. Geol. Sur. Can. Bul1. 367, $47 \mathrm{p}, 1987$.

oliver, J., Flulds expelled tectonically from orogenic belts: their role in hydrocarbon migration and other geologic phenomena, Geology, 14, 99-102, 1986.

Prasad, J.N., A paleomagnetic investigation of Early Paleozoic rocks in western Newfoundland, Ph.D. Thes is (unpublished), Memorial University of Newfoundland, 336 p., 1986.

Pullaiah, G., Irving, E., Buchan, K.L. and Dunlop, D.J., Magnetization changes caused by burial and uplift, Earth Planet. Sci. Lett. 28, 133-143, 1975 .

Ripperdan, R.L. and Kirschvink, J.L., Preliminary magnetic polarlty stratigraphy across the Cambrian-Ordovician boundary, Program and Abstracts, Fifth International Symposium on the Ordovician System, Memorial University of Newfoundland, 117 p., 1988.

Williams, H., Geology, Stephenville Map Area, Newfoundland, Geol.Sur. Gan. Map 1579A., 1985.

J.P. Hodych, Department of Earth Sciences, Memorial University of Newfoundland, St. John's, Newfoundland, A1B 3X7 Canada.

(Received: October 13, 1988; accepted: November 14, 1988.) 